Historic, Archive Document

Do not assume content reflects current scientific knowledge, policies, or practices. 



\section{Wholesale Trade List SPRING 1927}

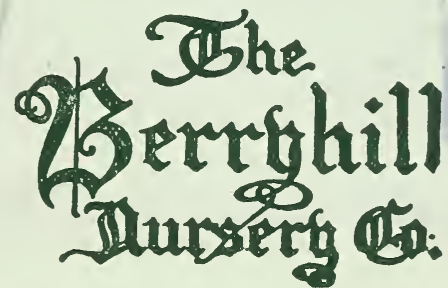

NURSERY

New Moorefield, Clark Co., Ohio

\section{OFFICE}

409 Mitchell Bldg., Springfield, Ohio

Members of The American Association of Nurserymen

Standardized Plant Names Used Throughout This List

\section{TERMS OF SALE}

SHIPMENTS. We prefer to have customers state by what method goods are to be shipped. In the absence of such instructions, we will use our own judgment, but our responsibility ceases when shipments are delivered to the freight or express companies for forwarding.

GUARANTEE. We exercise the greatest precaution and care to have our stock true to name, count and grade. It is mutually agreed between ourselves and customers that our guarantee in no case shall make us liable for any sum greater than that quoted. Stock delivered as per order and in good condition is not returnable. We endeavor to fill orders promptly or when specified. However; we cannot be held liable for orders cancelled while enroute.

PRICES AND TERMS. We will supply 5 at 10 rate, 25 at 100 rate, respectively. Items are cash with order to those unknown to us. To old customers and those supplying satisfactory reference the terms are 30 days net, with two per cent discount on bills paid in ten days from date of invoice. All claims must be made within five days.

Boxing and Baling Charged at Cost of Material and Labor Used 


\section{EVERGREEN TREES}

All Evergreen Trees and Shrubs have been twice or more transplanted to nursery row, and are dug with a ball of earth and burlaped.

Stock selected by customers at the nursery will be charged according to the value of the plants chosen, irrespective of catalog price.

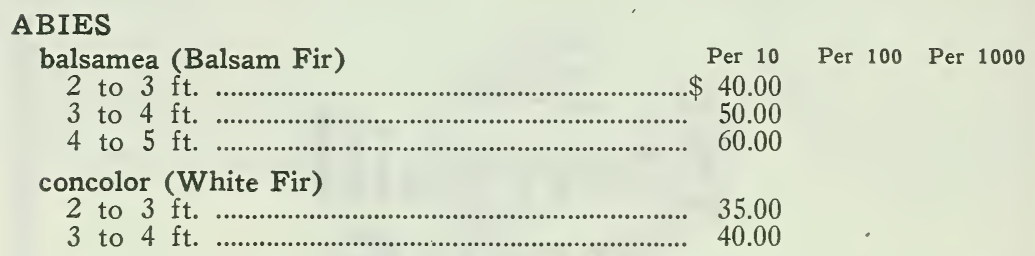

\section{CHAMAECYPARIS}

pisifera (Sawara Retinospora)

2 to $3 \mathrm{ft}$.

3 to $4 \mathrm{ft}$.

- aurea (Golden Sawara Retinospora)

3 to $4 \mathrm{ft}$.

50.00

-filifera (Thread Retinospora)

3 to $4 \mathrm{ft}$.

-plumosa aurea (Goldenplume Retinospora)

2 to $3 \mathrm{ft}$.

-squarrosa (Moss Retinospora)

18 to 24 in.

\section{JUNIPERUS}

chinensis pfitzeriana (Pfitzer's Juniper)

18 to 24 in.

2 to $21 / 2 \mathrm{ft}$.

3 to $31 / 2 \mathrm{ft}$.

communis (Common Juniper)

18 to 24 in.

24 to 30 in

22.50

3 to $4 \mathrm{ft}$............................................................ 35.00

4 to $5 \mathrm{ft}$. ............................................................... 50.00

-depressa (Prostrate Juniper)

2 to $3 \mathrm{ft}$.

3 to $3 \mathrm{I} / 2 \mathrm{ft}$.

-hibernica (Irish Juniper)

2 to $3 \mathrm{ft}$.

3 to $4 \mathrm{ft}$.

- suecica (Swedish Juniper)

15 to 18 in.

18 to $24 \mathrm{in}$.

2 to $3 \mathrm{ft}$.

3 to $4 \mathrm{ft}$.

excelsa stricta (Spiny Greek Juniper)

12 to 15 in.

15 to $18 \mathrm{in}$.

30.00

sabina (Savin Juniper)

15 to 18 in.

18 to 24 in. 


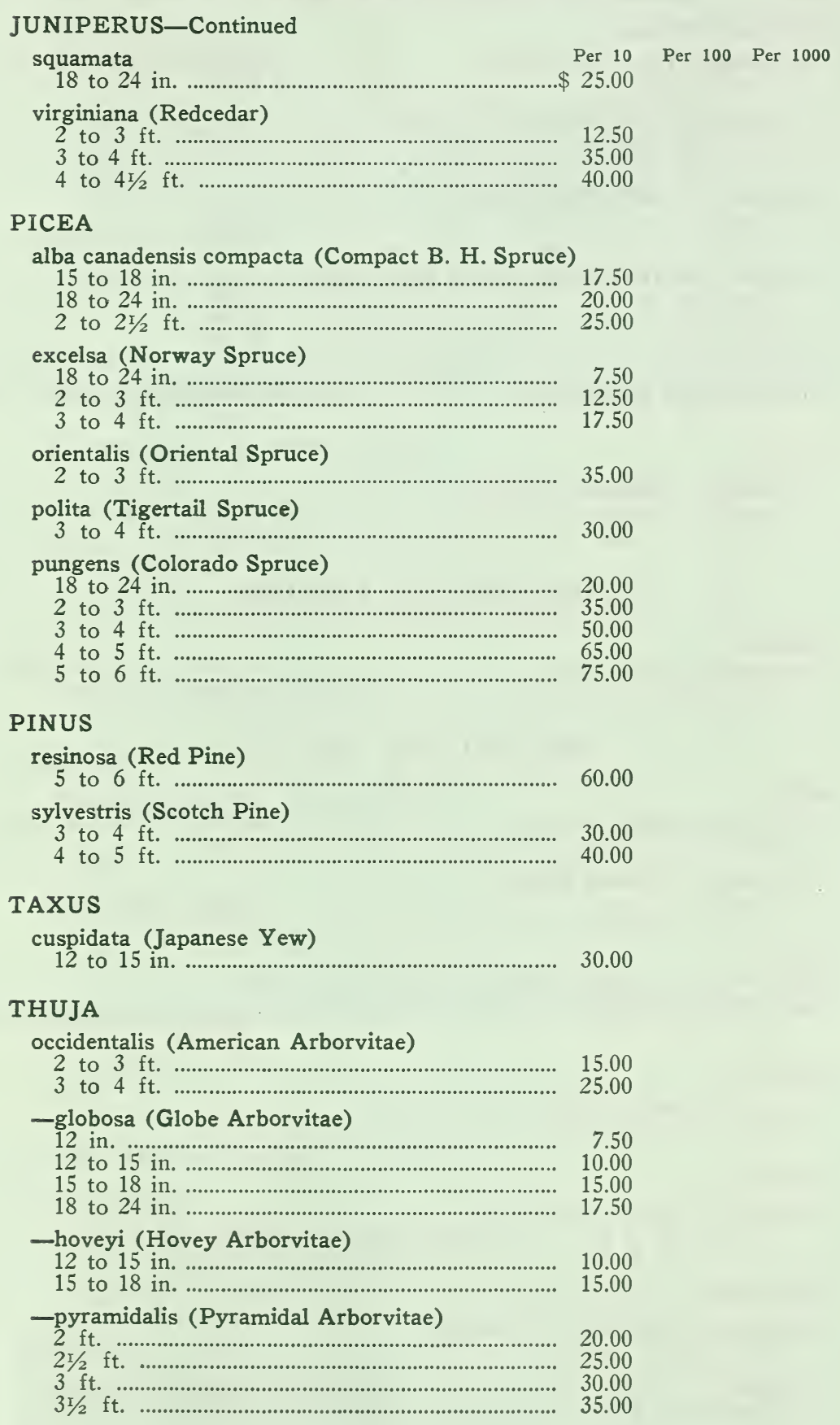




\section{THUJA-Continued}

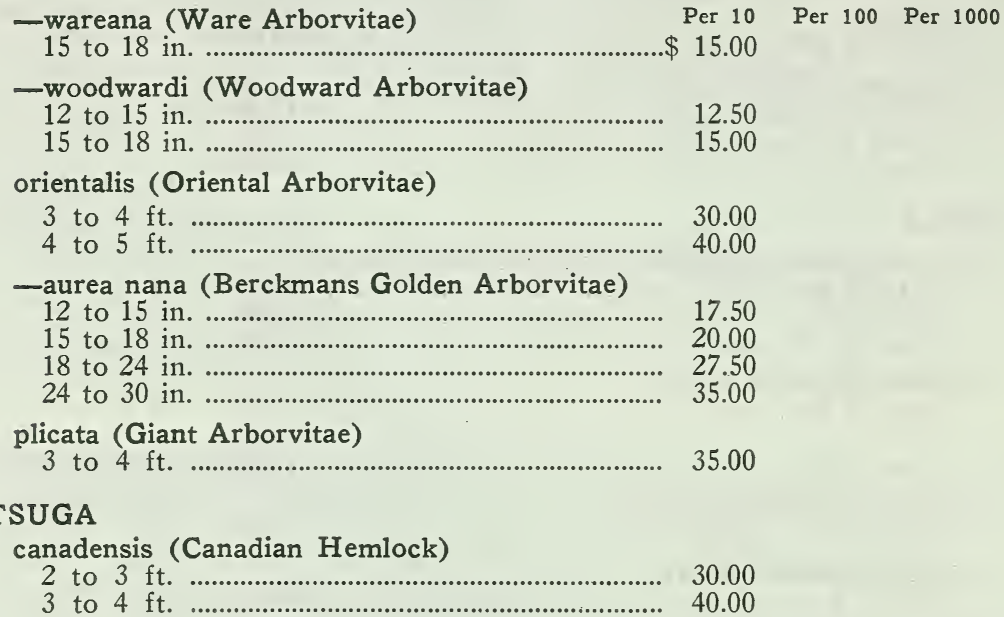

\section{EVERGREEN SHRUBS}

ABELIA

grandiflora (Glossy Abelia)

Per 10 Per 100 Per 1000

15 to 18 in.

\section{DECIDUOUS TREES}

ACER

dasycarpum (Silver Maple)

10 to $12 \mathrm{ft}$.

platanoides (Norway Maple)

7 to $8 \mathrm{ft}$. 1 year

6 to $8 \mathrm{ft}$. 2 year

Per 10 $\$ 12.50$

10.00

12.50

\section{BETULA}

alba (White Birch)

6 to $8 \mathrm{ft}$. B. \& B.

\section{CATALPA}

bungei (Umbrella Tree)

6 to $8 \mathrm{ft}$. 2 year heads

\section{CORNUS}

florida (Flowering Dogwood)

3 to $4 \mathrm{ft}$. B. \& B.

4 to $5 \mathrm{ft}$. B. \& B.

\section{FRAXINUS}

americana (American Ash, white)

8 to $10 \mathrm{ft}$. 


\begin{tabular}{|c|c|c|c|}
\hline LIRIODENDRON & Per 10 & Per 100 & Per 1000 \\
\hline 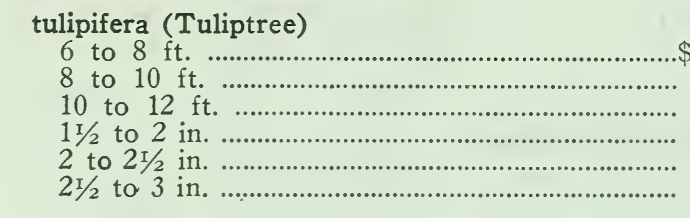 & $\begin{array}{r}9.00 \\
11.50 \\
12.50 \\
20.00 \\
25.00 \\
30.00\end{array}$ & & \\
\hline \multicolumn{4}{|l|}{ PLATANUS } \\
\hline $\begin{array}{l}\text { orientalis (European Plane) } \\
5 \text { to } 6 \mathrm{ft} .\end{array}$ & 6.50 & $\$ 60.00$ & \\
\hline \multicolumn{4}{|l|}{ POPULUS } \\
\hline $\begin{array}{l}\text { bolleana (Bolleana Poplar) } \\
6 \text { to } 8 \mathrm{ft} .\end{array}$ & 7.50 & & \\
\hline $\begin{array}{l}\text { nigra fastigiata (Lombardy Poplar) } \\
6 \text { to } 8 \mathrm{ft} . \\
8 \text { to } 10 \mathrm{ft} . \\
10 \text { to } 12 \mathrm{ft} .\end{array}$ & $\begin{array}{l}3.00 \\
4.00 \\
4.50\end{array}$ & $\begin{array}{l}25.00 \\
35.00 \\
40.00\end{array}$ & \\
\hline 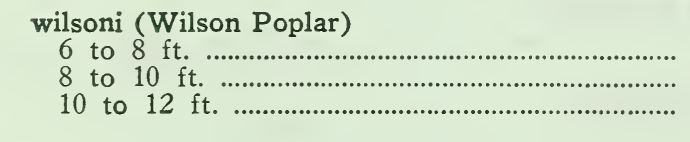 & $\begin{array}{l}3.50 \\
4.50 \\
5.50\end{array}$ & $\begin{array}{l}30.00 \\
40.00 \\
50.00\end{array}$ & \\
\hline \multicolumn{4}{|l|}{ SALIX } \\
\hline $\begin{array}{l}\text { babylonica (Weeping Willow) } \\
6 \mathrm{ft} .\end{array}$ & 4.00 & 35.00 & \\
\hline $\begin{array}{l}\text { SORBUS } \\
\text { americana (American Mountain Ash) } \\
6 \text { to } 8 \mathrm{ft} .\end{array}$ & 10.00 & & \\
\hline $\begin{array}{l}\text { ULMUS } \\
\text { fulva (Slippery Elm) } \\
\quad 8 \text { to } 10 \mathrm{ft} . \text {.................. }\end{array}$ & 15.00 & & \\
\hline
\end{tabular}

\section{DECIDUOUS SHRUBS}

ACANTHOPANAX

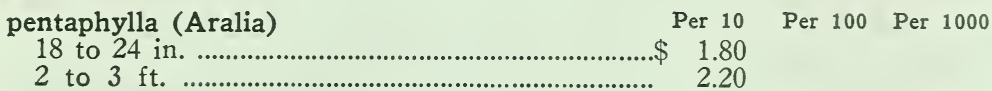

ALTHAEA (See Hibiscus)

AMYGDALUS

communis alba (White Flowering Almond)

2 to $3 \mathrm{ft}$. ................................................................ 3.50

-rosea (Pink Flowering Almond)
2 to $3 \mathrm{ft}$. .................................................................. 3.50

\section{BERBERIS}

thunbergi (Japanese Barberry)

18 to 24 in. 


\section{BERBERIS-Continued \\ -minor (Box Barberry) \\ 15 to 18 in. $3 \mathrm{yr}$. \\ BUDDLEIA \\ davidi magnifica (Oxeye Butterflybush) \\ 2 year}

Per 10 Per 100 Per 1000

$\$ \quad 5.00$

\section{CALLICARPA}

purpurea (Chinese Beautyberry)

18 to 24 in.

\section{COLUTEA}

arborescens (Common Bladder-Senna)

3 to $4 \mathrm{ft}$.

\section{CORNUS}

alba sibirica (Coral Dogwood)

$$
2 \text { to } 3 \mathrm{ft} \text {. }
$$

3 to $4 \mathrm{ft}$.

$1.80 \$ 16.00$

stolonifera (Red-Osier Dogwood)

2 to $3 \mathrm{ft}$.

3 to $4 \mathrm{ft}$.

$2.00 \quad 18.00$

-lutea (Goldentwig Dogwood)

2 to $3 \mathrm{ft}$.

\section{COTONEASTER}

acutifolia

18 to $24 \mathrm{in}$.

2 to $3 \mathrm{ft}$.

3 to $4 \mathrm{ft}$.

\section{CRATAEGUS}

oxycantha pauli (Pauls Scarlet Hawthorn)

5 to $6 \mathrm{ft}$.

\section{DEUTZIA}

gracilis (Slender Deutzia)

12 in. 3 year ............................................................ 1.80

15 to 18 in. ......................................................................... 2.00

lemoine (Lemoine Deutzia)

12 to $18 \mathrm{in}$.

18 to $24 \mathrm{in.}$

$2.20 \quad 20.00 \quad \$ 180.00$

scabra crenata

2 to $3 \mathrm{ft}$.

3 to $4 \mathrm{ft}$.

$2.50 \quad 22.00$

$1.50 \quad 12.00$

$1.80 \quad 15.00$

-fortunei (Fortune Deutzia)

2 to $3 \mathrm{ft}$.

3 to $4 \mathrm{ft}$

$2.20 \quad 18.00$

\section{ELAEAGNUS}

umbellata (Autumn Elaeagnus)

4 to $5 \mathrm{ft}$.

\section{EXOCHORDA}

grandiflora (Pearlbush)

3 to $4 \mathrm{ft}$. 


\begin{tabular}{|c|c|c|c|}
\hline RSYTHIA & & & \\
\hline suspensa (Weeping Forsythia) & Per 10 & Per 100 & Per 1000 \\
\hline $\begin{aligned} \text {-fortunei (Fortune Forsythia) } \\
2 \text { to } 3 \mathrm{ft} \\
3 \text { to } 4 \mathrm{ft}\end{aligned}$ & $\begin{array}{l}1.80 \\
2.00\end{array}$ & $\begin{array}{l}15.00 \\
18.00\end{array}$ & \\
\hline $\begin{aligned}- \text { intermedia (Border Forsythia) } \\
18 \text { to } 24 \mathrm{in.} \\
2 \text { to } 3 \mathrm{ft} . \\
3 \text { to } 4 \mathrm{ft}\end{aligned}$ & $\begin{array}{l}1.50 \\
1.80 \\
2.20\end{array}$ & $\begin{array}{l}12.00 \\
15.00 \\
18.00\end{array}$ & \\
\hline $\begin{array}{l}\text { - sieboldi (Siebold Forsythia) } \\
3 \text { to } 4 \mathrm{ft} .\end{array}$ & 3.00 & & \\
\hline $\begin{array}{l}\text { viridissima (Greenstem Forsythia) } \\
\quad 3 \text { to } 4 \mathrm{ft} .\end{array}$ & 1.80 & 15.00 & \\
\hline HAMAMELIS & & & \\
\hline $\begin{array}{l}\text { virginica (Common Witch-Hazel) } \\
18 \text { to } 24 \text { in. } \\
2 \text { to } 3 \text { ft. } \\
3 \text { to } 4 \mathrm{ft.}\end{array}$ & $\begin{array}{l}2.50 \\
3.50 \\
4.00\end{array}$ & & \\
\hline HIBISCUS (Shrub Althaea) & & & \\
\hline 18 to $24 \mathrm{in}$ & $\begin{array}{l}1.50 \\
2.00\end{array}$ & & \\
\hline HYDRANGEA & & & \\
\hline $\begin{array}{l}\text { paniculata grandiflora (true) } \\
18 \text { to } 24 \text { in. } \\
2 \text { to } 3 \mathrm{ft} .\end{array}$ & $\begin{array}{l}2.50 \\
3.00\end{array}$ & $\begin{array}{l}22.00 \\
25.00\end{array}$ & \\
\hline 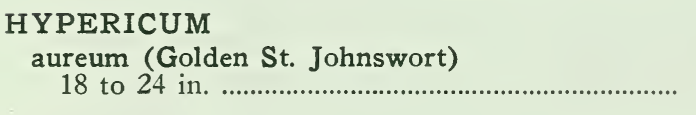 & 2.50 & 22.00 & \\
\hline LIGUSTRUM & & & \\
\hline $\begin{array}{l}\text { amurense, north } \\
2 \text { to } 3 \mathrm{ft} . \\
3 \text { to } 4 \mathrm{ft.}\end{array}$ & & $\begin{array}{l}10.00 \\
12.00\end{array}$ & $\begin{array}{r}\$ 80.00 \\
100.00\end{array}$ \\
\hline $\begin{array}{l}\text { ibota (Ibota Privet) } \\
2 \text { to } 3 \text { ft. }\end{array}$ & & 8.00 & 70.00 \\
\hline $\begin{array}{l}\text { ovalifolium (California Privet) } \\
18 \text { to } 24 \text { in. }\end{array}$ & & & 35.00 \\
\hline $\begin{array}{l}\text { vulgarie (Common Privet) } \\
3 \text { to } 4 \mathrm{ft} .\end{array}$ & & 12.00 & \\
\hline LONICERA & & & \\
\hline $\begin{array}{l}\text { fragrantissima (Winter Honeysuckle) } \\
18 \text { to } 24 \mathrm{in.} \\
2 \text { to } 3 \mathrm{ft} .\end{array}$ & $\begin{array}{l}1.50 \\
1.80\end{array}$ & $\begin{array}{l}12.00 \\
15.00\end{array}$ & \\
\hline $\begin{array}{l}\text { maacki (Amur Honeysuckle) } \\
3 \text { to } 4 \mathrm{ft} .\end{array}$ & 2.50 & & \\
\hline $\begin{aligned} \text { morrowi } & \\
2 & \text { to } 3 \\
3 & \text { to } 4 \mathrm{ft} .\end{aligned}$ & $\begin{array}{l}1.50 \\
1.80\end{array}$ & $\begin{array}{l}12.00 \\
15.00\end{array}$ & \\
\hline
\end{tabular}




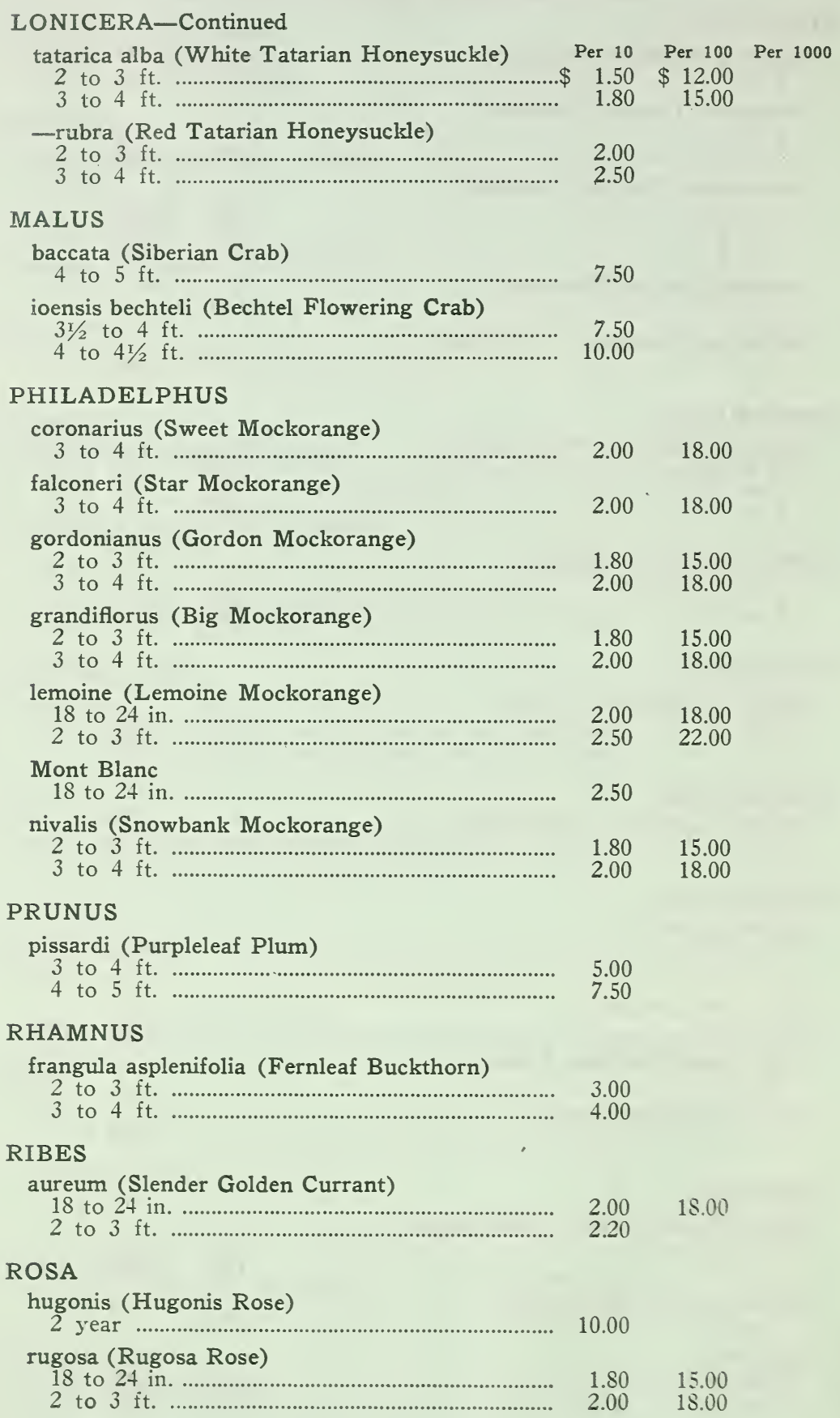




\section{SAMBUCUS}

canadensis aurea (Golden Elder)

2 to $3 \mathrm{ft}$.

3 to $4 \mathrm{ft}$.

Per 10 Per 100 Fre 1000

4 to $5 \mathrm{ft}$.

$200 \$ 18(0)$

$2.20 \quad(0)(010$

$2.50 \quad 2200$

\section{SPIRAEA}

\section{bumalda Anthony Waterer}

12 to 15 in. 3 year …........................................ $1.80 \quad 15.00$

15 to 18 in.

$\therefore 00 \quad 18.00$

-froebeli (Froebel Spiraea)

15 to 18 in.

$1.80 \quad 15.0()$

japonica alba (Japanese Spiraea)

12 to 15 in.

$1.80 \quad 15.00$

-rubra (Red Japanese Spiraea)

15 to 18 in.

$1.80 \quad 15.00$

prunifolia (Bridalwreath)

18 to $24 \mathrm{in}$.

2 to $3 \mathrm{ft}$.

$2.00 \quad 15.00$

$2.50 \quad 22 .(0)$

thunbergi (Thunberg Spiraea)

15 to $18 \mathrm{in}$.

$1.80 \quad 15.00$

18 to $24 \mathrm{in}$.

$2.00 \quad 18.00$

vanhouttei (Vanhoutte Spiraea)

18 to 24 in.

2 to $3 \mathrm{ft}$.

3 to $4 \mathrm{ft}$.

\section{SYRINGA}

chinensis (Rothamagensis)

2 to $3 \mathrm{ft}$.

vulgaris (Common Lilac)

18 to $24 \mathrm{in}$.

-tree

3 to $4 \mathrm{ft}$.

-alba

18 to 24 in

2 to 3 it.

\section{TAMARIX}

africana (African Tamarix)

2 to 3 it.

3 to 4 it.

\section{VIBURNUM}

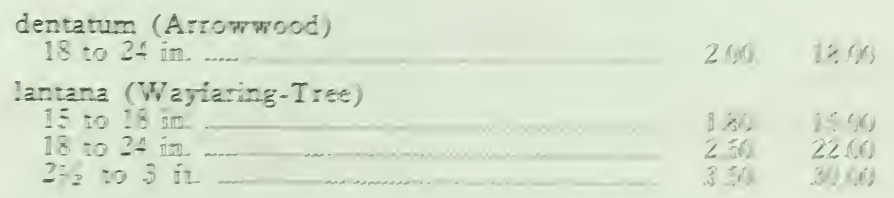






\section{GRASS}

\section{PHALARIS}

Per 10 Per 100 Per 1000

heavy clumps

$\$ 2.50$

\section{PERENNIALS AND GROUND COVER}

IRIS

mixed

purple

sibirica
Per 10

3.00
3.00
3.00

\section{PACHYSANDRA}

terminalis (Japanese Pachysandra)

$21 / 2$ in. pots

3 in. pots

$10.00 \$ 80.00$

$12.00 \quad 100.00$

\section{VINCA}

minor (Common Periwinkle)

$2 \frac{x}{2}$ in. pots

\section{VINES}

\section{CELASTRUS}

scandens (Bittersweet)

2 yr.

3 yr. 


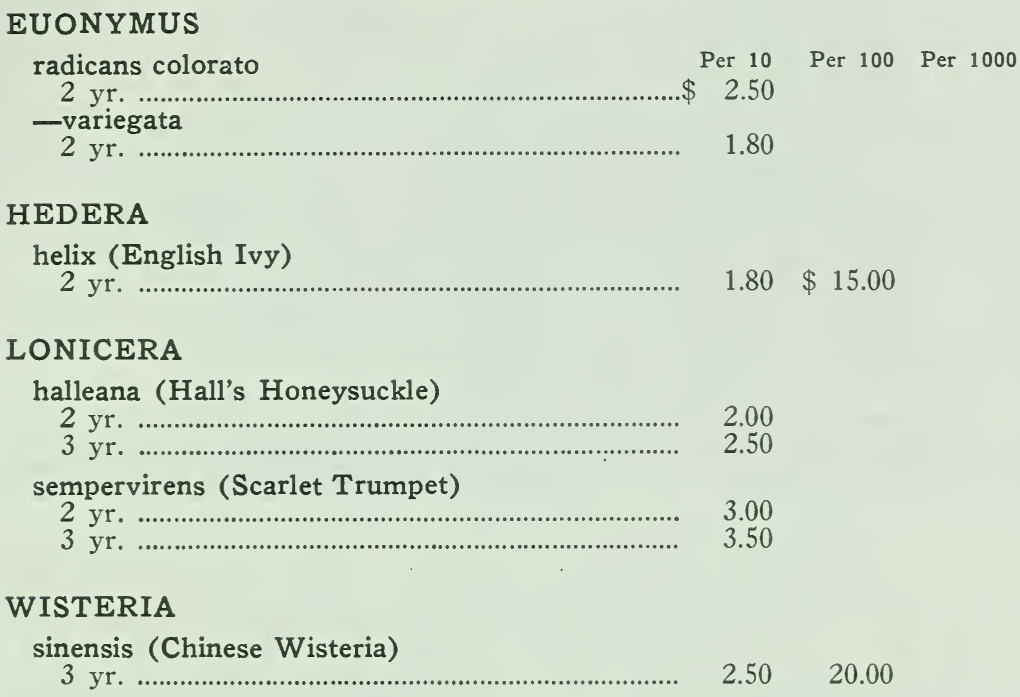

\section{FRUITS}

APPLES, $X X$ in variety

Per 10 Per 100 Per 1000

1 in. and up $\$ 6.00 \$ 50.00$

CHERRIES, $\mathrm{XX}$ in variety

1 in. and up

$7.50 \quad 60.00$

PEACHES, $\mathrm{XX}$ in variety

1 in. and up

$5.00 \quad 40.00$

PEARS, $\mathrm{XX}$ in variety

1 in. and up

$7.00 \quad 65.00$

PLUMS, $\mathrm{XX}$ in variety

1 in. and up

\section{GRAPES}

Agawam

2 yr. No. 1

Concord

2 yr. No. 1

Niagara

2 yr. No. 1 


\section{LINING-OUT STOCK}

The following stock is out of $2 \frac{1}{2}$ in. pots, well finished and will carry in an excellent condition.

\section{CLIMBING ROSES}

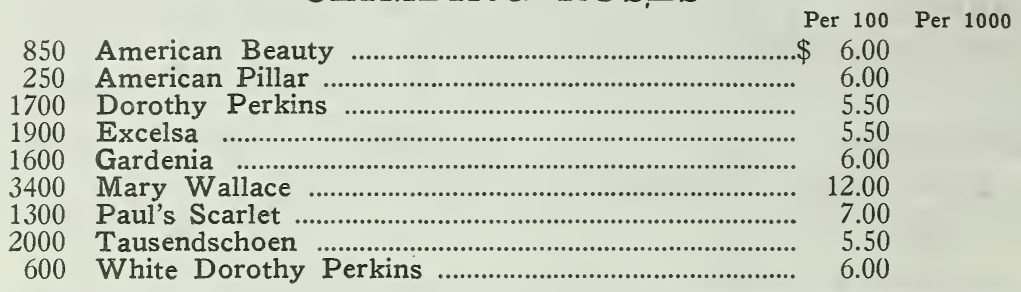

\section{BUSH ROSES}

400 Hugonis

750 Gruss an Teplitz .

Per 100 Per 1000 $\$ 10.00$

6.50

\section{DECIDUOUS SHRUBS}

3700

15000

2500

33000

7000

19000

3000

14000

12500

4200

7000

7000

32400

5200

5800

15000

5000

7800

3300

7500

2800
Acanthopanax pentaphylla

Buddleia

Cotoneaster acutifolia

Deutzia gracilis

Deutzia gracilis rosea

Deutzia lemoine

Euonymus alatus-true

Hydrangea arborescens grandifiora

Hydrangea paniculata grandiflora-true

Philadelphus aurea

Philadelphus Mont Blanc

Philadelphus virginal

Spiraea bumalda Anthony Waterer

Spiraea prunifolia

Spiraea thunbergi

Syringa chinensis

Viburnum opulus

Viburnum opulus sterilis

Viburnum tomentosum

Ampelopsis veitchi, 1 yr. seedlings

Rhodotypos, 10 to 15 in. seedlings
Per 100 Per 1000

$\$ 7.00 \$ 60.00$

$6.00 \quad 50.00$

$\begin{array}{ll}7.00 & 60.00\end{array}$

$6.00 \quad 50.00$

$7.00 \quad 60.00$

$6.00 \quad 50.00$

$9.00 \quad 80.00$

$6.50 \quad 60.00$

$8.00 \quad 70.00$

$8.00 \quad 70.00$

$8.00 \quad 70.00$

$8.00 \quad 70.00$

$5.00 \quad 45.00$

$8.00 \quad 70.00$

$6.50 \quad 60.00$

$8.00 \quad 70.00$

$8.00 \quad 70.00$

$8.00 \quad 70.00$

$9.00 \quad 80.00$

25.00

6.00

\section{EVERGREENS}

Chamaecyparis pisifera, 10 to 15 in. 2 yr. bedded........\$ 25.00 Juniperus horizontalis glauca ....................................... 12.00

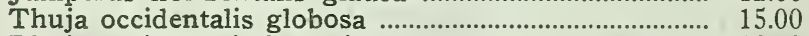

Thuja occidentalis hoveyi ……....................................... 12.00

Thuja occidentalis pyramidalis ...................................... 15.00

Thuja occidentalis reidi ..................................................... 12.00

Thuja occidentalis wareana .............................................. 12.00

Thuja occidentalis woodwardi ............................................ 15.00 